\title{
PERANCANGAN PENGAMANAN AKUN DENGAN \\ MENGGUNAKAN MAC ADDRESS PADA METODE ENKRIPSI DES
}

\author{
Marihot Tora Tambunan', Wiwin Sulistyo \\ ${ }^{1,2)}$ Program Studi Teknik Informatika, Universitas Kristen Satya Wacana (UKSW) \\ Jl. Diponegoro 52-60, Salatiga 50711 \\ Telp : (0298) 321212 \\ Email : 672011056@student.uksw.edu, wiwinsulistyo@staff.uksw.edu
}

\begin{abstract}
Account security becomes very important as rapid development of internet and access. The case that was reported by Liputan6 about username and password stealing done by a hacker proves that sniffing exists in reality. One of encryption method, which can be used to secure an account's user id and password, is DES (Data Encryption Standard). However, this algorithm is not always considered secure. Because of that, the researcher used mac address score for the authentication step during the log in process. It is done to cover flaw since DES encryption has been prone to be broken. The result of the examination shows that mac address is possible to be used during the authentication step. This model is also efficient to be used because the response duration is quiet quick, which is less than a second, even though the first trial would take some time and process to enter the system. This model can be used as server identifier to enable user to get login access by checking mac that has been exist in the user's device.
\end{abstract}

Keywords: Data Encryption Standard (DES), Authentication, Login, Mac Addres

\section{PENDAHULUAN}

Pengamanan sebuah akun menjadi sesuatu yang sangat penting. Hal ini dapat dilihat dari perkembangan internet yang sangat pesat dan akses yang mudah. Kemungkinan adanya sniffing atau penyadapan dalam internet membuat user id dan password akun rawan dicuri oleh orang lain. Seperti pada kasus yang diberitakan oleh Liputan6 bahwa username dan password dari pengguna Dropbox dicuri oleh hacker (Maulana, 2014). Walaupun dalam berita ini pihak Dropbox

mengungkapkan bahwa pihaknya tidak diretas, namun bisa dilihat keamanan akun bisa diretas oleh hacker saat pengguna Dropbox menggunakan aplikasi layanan lain yang berkaitan dengan Dropbox. User id dan password yang menjadi data wajib diamankan ketika dikirimkan ke server atau ke layanan yang lain, salah satu cara yang digunakan untuk mengamankan adalah dengan enkripsi (Rahardjo, 1999).

Enkripsi merupakan proses yang dilakukan untuk mengamankan sebuah 
pesan (yang disebut plaintext) menjadi pesan tersembunyi (yang disebut chipertext), dan proses sebaliknya dari chipertext menjadi plaintext disebut dekripsi (Rahardjo, 1999). Proses enkripsi dan dekripsi terdiri dari dua prinsip, yaitu symmetric cryptograph dan public-key cryptograph. Prinsip symmetric menggunakan kunci yang sama untuk enkripsi dan dekripsi, sedangkan prinsip public-key menggunakan kunci yang berbeda saat enkripsi (public key) dan dekripsi (private key).

Algoritma enkripsi Data Encryption Standard (DES) adalah sebuah algoritma enkripsi yang menggunakan prinsip symmetric. Saat ini satu-satunya cara yang diketahui untuk mendobrak sandi DES adalah dengan mencoba satu per satu berbagai kombinasi kunci (brute force attack) (Khairina, 2011). Kekuatan keamanan dari algoritma ini banyak bergantung pada ukuran kunci yang digunakan (dalam bit) (Nugroho, 2007). Namun, algoritma ini tidak selamanya dianggap aman. Pada tanggal 16 juni 1998 ada sebuah kelompok yang menamakan dirinya Electronic Frontier Foundation (EFF) telah berhasil memecahkan algoritma DES dalam waktu 4-5 hari menggunakan komputer yang dilengkapi dengan Integrated Circuit Chip DES Cracker (Khairina, 2011).

Salah satu aspek dalam keamanan komputer adalah authentication. Aspek ini berhubungan dengan metoda untuk menyatakan bahwa informasi betulbetul asli, atau orang yang mengakses atau memberikan informasi adalah betul-betul orang yang dimaksud (Rahardjo, 1999). Penulis mengidentifikasi dari perangkat keras yang digunakan untuk mengakses, yaitu Mac Address, karena nilai dari tiap-tiap perangkat berbeda-beda dan unik. Maka untuk menambahkan pengamanan dalam enkripsi DES, penulis menambahkan nilai mac address dalam proses authentication.

Dalam tulisan ini, penulis membuat kombinasi mac address dan metode enkripsi DES untuk menghasilkan proses otentikasi password, dan username. Jadi, penulis meningkatkan keamanan akun yang telah di enkripsi DES dengan menambahkan mac address pada proses otentikasi.

Penelitian ini akan lebih menekankan cara untuk login atau sistem login. Seperti penelitian yang dilakukan oleh Khairina tentang analisa 
kemanan sistem login. Dari penelitian tersebut disimpulkan bahwa penting untuk mengenkripsi data (password) pada sebelum dikirim ke server (Khairina, 2011).

\section{Proses}

penyandian

membutuhkan sebuah algoritma enkripsi, salah satunya adalah algoritma Data Encryption Standard (DES). Pada makalah yang dituliskan oleh Nugroho, algoritma DES menggunakan panjang kunci 56 bit dan proses enkripsi dilakukan sebanyak 16 kali putaran, sehingga keamanan DES sangat bergantung pada ukuran kunci yang digunakan (dalam bit). Walaupun algoritma ini sudah menjadi tidak aman, masih ada solusi yang dapat digunakan, yaitu dengan menggunakan panjang kunci lebih dari 64 bit, seperti algoritma Triple DES menggunakan kunci 2x56 atau 112 bit (Nugroho, 2007).

Al-Husainy menyebutkan bahwa setiap perangkat jaringan dilengkapi dengan alamat perangkat keras unik secara global yang disebut $M A C$ address (Al-Husainy, 2013). MAC address terdiri dari 12 angka heksadesimal (panjang 48 bit). Angka pada MAC address dibagi menjadi dua bagian, bagian pertama menjelaskan nomor identitas adaptor pabrikan, dan bagian kedua menjelaskan nomor serial yang diberikan ke adaptor oleh pabrikan. Keunikan MAC address sangat penting dalam semua tahap komunikasi jaringan, karena $M A C$ address memetakan semua pengenal di upper-layer (Al-Husainy, 2013).

Penelitian terkait penggunaan MAC address sudah pernah dilakukan sebelumnya. Adikara dalam penelitiannya, yaitu "Pemanfaatan MAC Address Hotspot Dalam Pengembangan Sistem Absensi GPS Dalam Rangka Meningkatkan Keakuratan Posisi Pengguna" menyimpulkan bahwa GPS dan MAC address mampu memberikan hasil yang saling melengkapi dan berjalan bersama-sama dalam satu aplikasi Android untuk memberikan lokasi yang lebih akurat dan tepat dari seseorang, serta MAC address mampu menghasilkan informasi SSID sebagai titik lokasi dengan hasil yang tepat (Adikara, 2015). Dengan beberapa kesimpulan dari penelitian ini, maka MAC address dapat digunakan sebagai identitas unik dari sebuah perangkat untuk masuk kedalam sistem.

METODE 
Penelitian yang dilakukan menggunakan metode penelitian berbasis Pemodelan. Metode penelitian berbasis pemodelan adalah penelitian yang menghasilkan sebuah metode untuk mendesain pemodelan dalam ilmu komputer (Sulistyo dan Subanar, 2013). Adapun hasil dari penelitian ini akan menghasilkan sebuah model yang diharapkan dapat digunakan. Tahapantahapan dalam metode penelitian ini adalah sebagaimana pada Gambar 1.

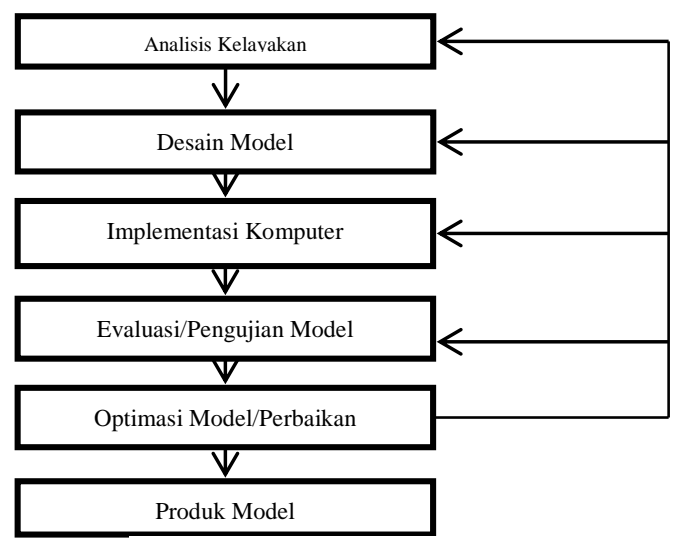

Gambar 1. Tahapan Metode

Didalam tahap analisis kelayakan terdapat beberapa hal yang menjadi perhatian, yaitu identifikasi masalah, hipotesis, rumusan masalah, identiikasi tujuan (tujuan penelitian), dan pembatasan masalah. Pada tahap desain model, akan ditentukan metode/algoritma yang digunakan sebagai acuan untuk dapat menggambarkan model yang dirancangkan. Metode yang digunakan adalah metode penelitian pengembangan. Dalam implementasi komputer akan digunanakan beberapa tools, yaitu sistem operasi Windows 10 dan Windows 7, bahasa pemrograman yang digunakan adalah C\# menggunakan library .NET Framework 4.

\section{Analisis Kelayakan}

Identifikasi masalah dalam penelitian ini adalah penggunaan akun di dunia internet semakin banyak sehingga pengguna menjadi waspada apabila tidak ada pengamanan didalam akun tersebut. Pengamanan dapat berupa enkripsi, salah satu algoritma enkripsi adalah Data Encription Standart (DES), karena algoritma ini menggunakan kunci yang sama untuk menyandikan dan mengembalikan.

Hipotesis dalam penelitian ini adalah dengan menambahkan mac address saat proses otentikasi, maka akun yang sedang melakukan proses login akan teridentifikasi, sehingga akun yang dienkripsi menggunakan DES dapat lebih aman. Nugroho dalam penelitiannya mengatakan bahwa algoritma enkripsi DES adalah algoritma yang sudah tidak aman, karena sudah banyak orang yang 
mencoba untuk membongkar algoritma ini dan waktu untuk membongkar algoritma ini hanya membutuhkan waktu yang singkat (Nugroho, 2007). Lalu Rahardjo menyebutkan dalam aspek keamanan ada bagian otentikasi, aspek ini berhubungan dengan informasi yang dimiliki oleh pengguna. Aspek ini menyatakan orang yang mengakses adalah orang yang sebenarnya dengan menggunakan ciri khasnya (Rahardjo, 1999). MAC Address (Media Access Control Address) adalah sebuah alamat jaringan yang diimplementasikan pada lapisan data-link dalam tujuh lapisan model OSI, yang mempresentasikan sebuah node tertentu dalam jaringan (Primartha, 2011).

Identifikasi dari penelitian ini adalah bagaimana merancang pengamanan akun dengan menambahkan mac address sebagai pengenal pemilik akun dalam metode enkripsi DES. Dan manfaat dari penelitian ini adalah meminimalkan penyalahgunaan data atau informasi yang ada di dalam akun.

Pembatasan masalah dalam penelitian ini adalah pengamanan yang dilakukan pada data akun username dan password. Algoritma enkripsi yang digunakan adalah algoritma DES.

\section{Desain Model}

Dari kajian pustaka yang telah dilakukan, penulis kemudian membuat sebuah skenario yang akan dijalankan dalam penelitian ini. Skenario ini memperlihatkan proses dari awal seorang user melakukan login hingga sampai otentikasi. Ada sedikit perbedaan dalam skenario ini, yaitu mengambil mac address secara otomatis ketika user login. Skenario ini dapat dilihat dari Gambar 2 dan Gambar 3.

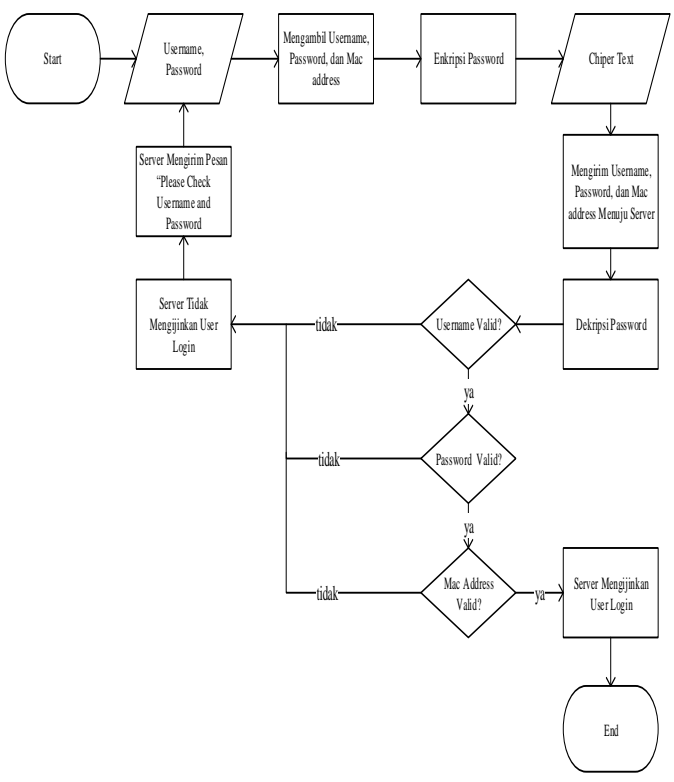

Gambar 2. Desain Model Sistem 


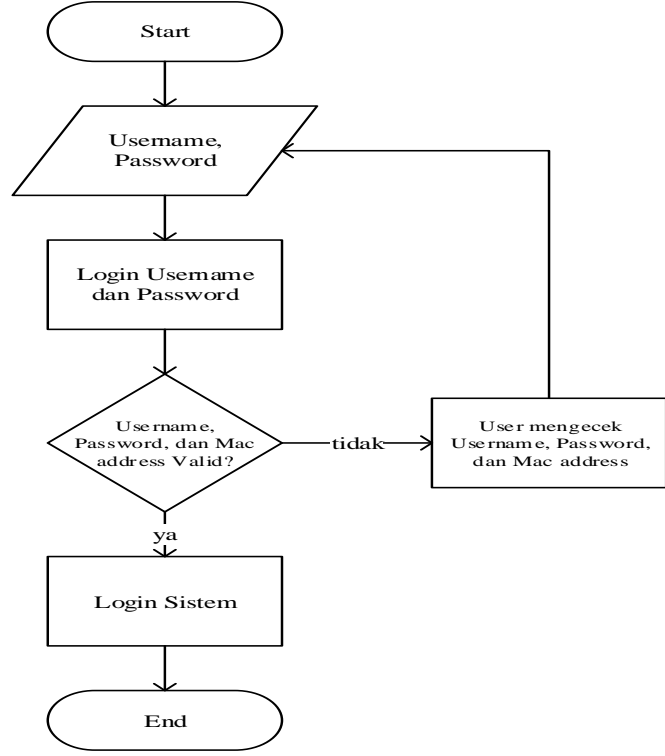

Gambar 3. Desain Model User

Interface

Menurut Primartha, skema global dari algoritma DES dimulai dari konversi plaintext menjadi bentuk biner, lalu blok plaintext dipermutasi dengan matriks permutasi awal, kemudian hasil dari permutasi akan dienchipering sebanyak 16 kali menggunakan kunci internal yang berbeda-beda, setelah itu hasil enchipering dipermutasi dengan matriks permutasi balikan menjadi blok chiper (Primartha, 2011). Skema enkripsi dapat dilihat dalam Gambar 4.

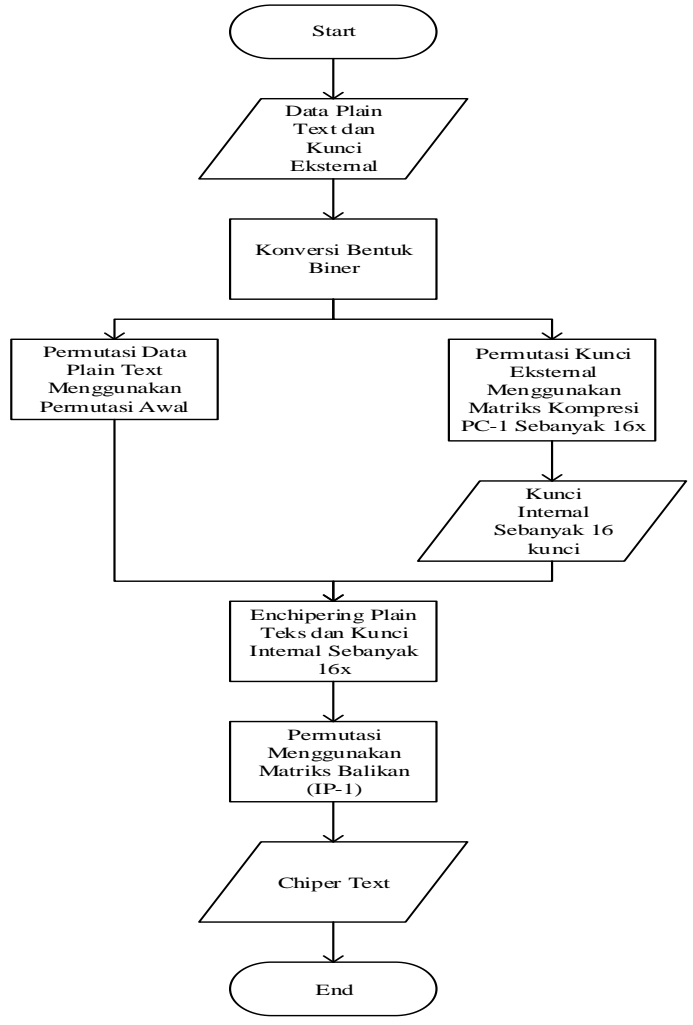

Gambar 4. Desain Enkripsi DES (Primartha, 2011)

Dalam penelitian Saikumar (2017), gambaran secara rinci proses enkripsi DES 16 putaran dapat dilihat pada Gambar 5. Dari gambar ini proses enkripsi dilakukan setelah diubah menjadi bentuk biner kemudian blok putaran dibagi menjadi dua bagian yang sama, dengan data bit bagian Li 32 bit dan data bagian $\mathrm{Ri} 32$ bit. Proses enchipering pertama mulai dilakukan dengan menggunakan $\mathrm{K}_{1} \quad$ (kunci internal) hingga 16x. 


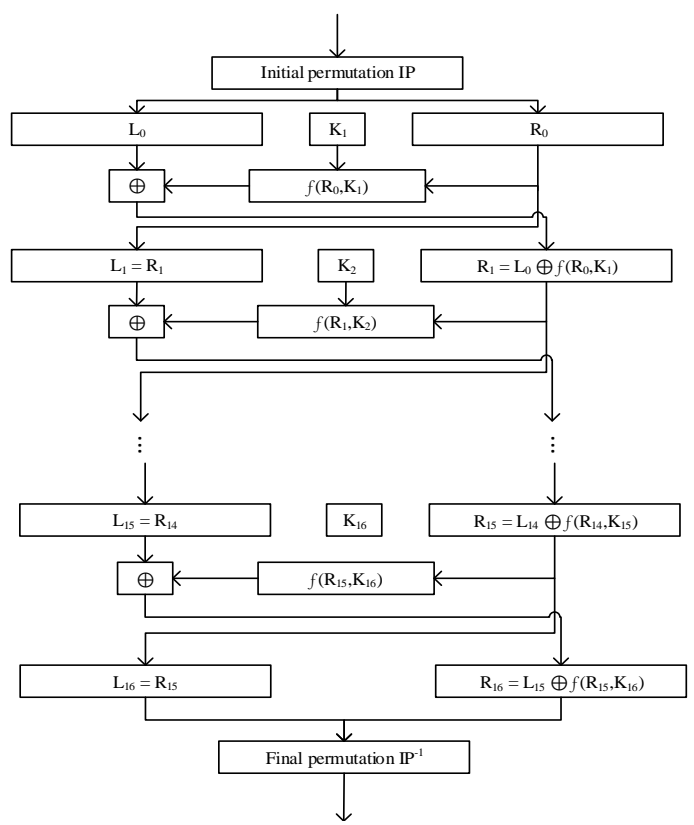

Gambar 5. Algoritma DES dengan 16

Putaran (Saikumar, 2017)

Seorang pengguna dapat menggunakan akun dimana saja dan kapan saja, namun perangkat yang digunakan dapat berbeda.. Untuk itu ketika proses login sistem akan mengambil data mac address dari perangkat yang digunakan. Kemudian server akan memverifikasi untuk dapat login atau tidak dengan mengecek data mac address yang diambil dengan yang ada di server. Pada penelitian ini diasumsikan bahwa sebuah akun telah terdaftar dan memiliki data yang telah tersimpan di server.

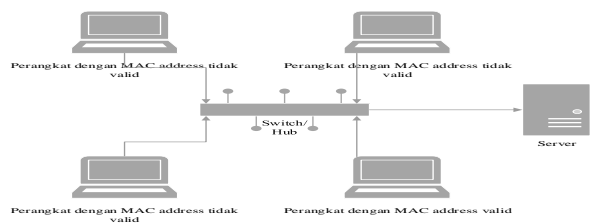

3. Gambar 6. Arsitektur Jaringan
Gambaran aplikasi yang digunakan terlihat pada Gambar 7.

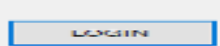

Gambar 7. Form Login

\section{Kode Program 1 Enkripsi DES}

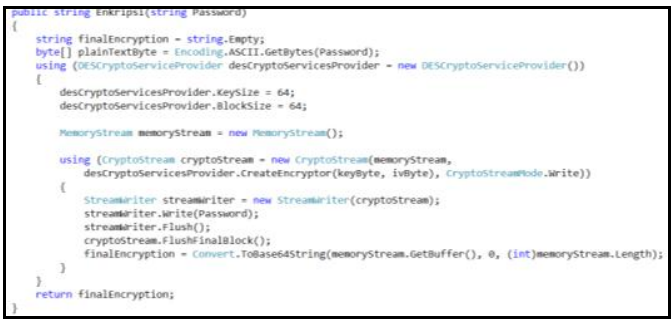

Gambar 8. Kode Program Enkripsi DES

Kode Program 1 adalah script untuk mengenkripsi password yang akan dikirim menuju server.

Kode Program 2 Mengambil Nilai Mac Address

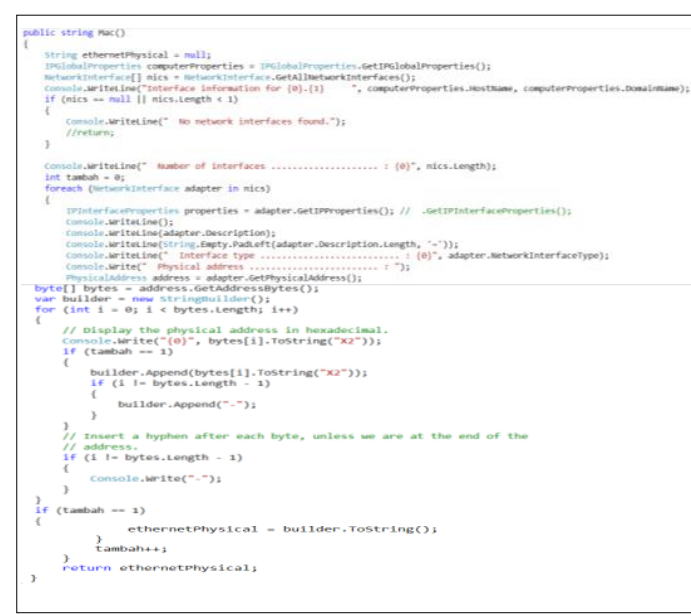

Gambar 9. Kode Program Mengambil Nilai Mac Address

Kode Program 4 adalah script untuk mengambil nilai mac address yang ada di perangkat. 


\section{HASIL DAN PEMBAHASAN}

\section{Evaluasi / Pengujian Model}

\begin{tabular}{|c|c|c|c|}
\hline \multicolumn{3}{|c|}{ Queryli Queryyy...UMENTSIDATA.MDF } & Login: Quenyyo...UMENTSIDAT \\
\hline & usemame & password & MAC_Address \\
\hline & baju & pass & $20-6 A-8 A-71-66-52$ \\
\hline$n$ & NULL & NOLL & NULL \\
\hline
\end{tabular}

Gambar 10. Database tersimpan di Server

Pada tahap ini dilakukan proses verifikasi, yang bertujuan untuk menguji model dalam sebuah aplikasi telah berjalan dengan konsep yang telah dibuat. Akun pertama di dalam database telah tersimpan satu akun dengan username, password, dan mac address seperti yang ada di Gambar 10. Dalam proses verifikasi dan validasi menggunakan empat perangkat berbeda.

\section{a. Perangkat Pertama}

Dalam penelitian ini setiap kali user melakukan login, maka mac address yang akan dikirim ke server adalah mac address dari interface yang kedua, yaitu 20-6A-8A-71-52. Terlihat pada Gambar 11.

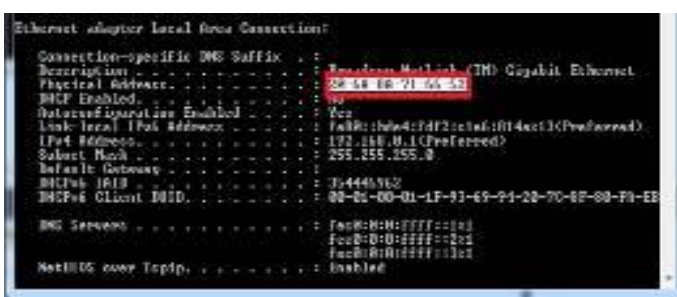

Gambar 11. Identifikasi Mac Address
Server akan menerima apa yang telah dikirim oleh client. Terlihat pada Gambar 12 bahwa client melakukan login dengan alamat 192.168.0.1, username "bayu", password yang telah terenkripsi, dan mac address 20-6A-8A71-66-52 dari perangkat client.

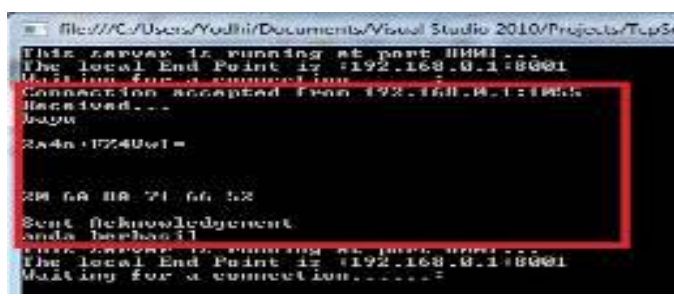

Gambar 12. Data Yang Diterima Server Dari Perangkat Pertama

Client telah berhasil login dengan akun yang bernama "bayu" dan juga mac address yang sesuai dengan yang tersimpan di dalam database. Dari sini terlihat bahwa sistem akan mengijinkan client untuk login dengan data yang sesuai di database. Dari Gambar 13 terlihat bahwa user telah masuk ke dalam sistem dan muncul user interface baru.

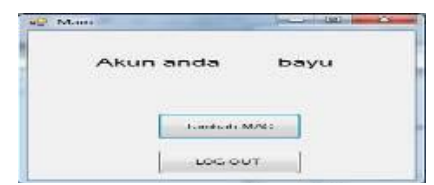

Gambar 13. Akun Bayu Berhasil Login

Berikutnya proses validasi untuk melihat sistem dapat dijalankan apabila mac addreess tidak sesuai dengan yang terdapat didalam database. 
b. Perangkat Kedua

Pada perangkat yang kedua nilai mac addrress B8-70-F4-36-3B berbeda dengan yang tersimpan didalam database.

User melakukan login melalui perangkat kedua dengan alamat 192.168.0.2, sistem kemudian akan menolak akses untuk user. Untuk dapat login perlu kesesuaian dengan mac address yang ada di perangkat dengan yang ada di database.

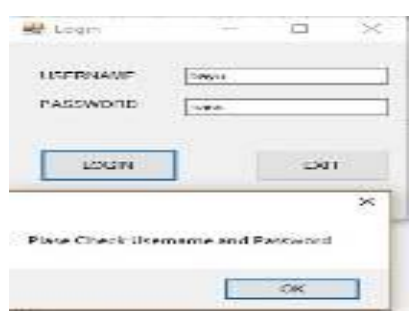

Gambar 14. Akun Bayu Gagal Login

Untuk dapat login melalui perangkat yang kedua, user harus masuk melalui perangkat pertama. Setelah masuk user dapat menambahkan nilai mac yang lain.

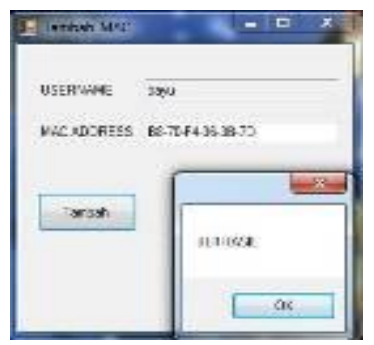

Gambar 15. Menambah Mac Address

melalui perangkat kedua. Proses login berhasil. Terekam didalam server perangkat kedua menggunakan alamat
192.168.0.2 untuk login, dengan username "bayu" dan password yang terenkripsi, serta nilai mac address B870-f4-36-3B-7D.

c. Perangkat Ketiga

Pada perangkat ketiga terdapat nilai mac yang berbeda dengan yang disimpan didalam database, yaitu 6A14-01-60-15-FB.

User kembali melakukan login melalui perangkat ketiga dengan alamat 192.168.0.3, sistem kemudian akan menolak akses. Nilai mac address 6A14-01-60-15-FB belum ada tersimpan didalam database server.

Pada kasus ini user kembali melakukan login dari perangkat kedua. User menambahkan nilai mac dari perangkat ketiga, yaitu 6A-14-01-6015-FB.

User kembali mencoba login melalui perangkat ketiga dan proses login berhasil. Terekam didalam server perangkat kedua menggunakan alamat 192.168.0.3 untuk login, dengan username "bayu" dan password yang terenkripsi, serta nilai mac address 6A14-01-60-15-FB.

d. Perangkat Keempat

Pada perangkat keempat terdapat nilai mac yang berbeda dengan 
yang disimpan didalam database, yaitu 34-23-87-85-64-09.

User kembali melakukan login dari perangkat ketiga melalui alamat 192.168.0.3. User menambahkan nilai mac dari perangkat keempat, yaitu 3423-87-85-64-09.

User mencoba login melalui perangkat keempat. Proses login berhasil dan terekam server perangkat keempat menggunakan alamat 192.168.0.4 dengan username "bayu" dan password yang terenkripsi, serta nilai mac address 34-23-87-85-64-09.

Selama proses pengujian menggunakan empat perangkat, database yang ada didalam server selalu terupdate. Terlihat dalam Gambar 16 username dan password hanya terdapat satu akun saja, tetapi memiliki empat nilai mac address yang berbedabeda.

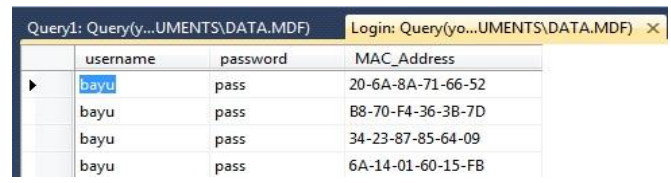

Gambar 16. Database Server

Awal mula dari penelitian ini menggunakan data yang telah diisi pada database, mulai dari username, password, dan mac address. Data pertama yang ada dalam pengujian ini disebut perangkat 1, yaitu dengan mac address 20-6A-8A-71-66-52.

Saat proses pengujian, server merekam data yang masuk, yaitu username, password, dan mac address. Sistem telah mengambil data sesuai dengan yang telah dirancangkan dan user berhasil login dengan password yang dienkripsi saat dikirim. Berikutnya menggunakan 3 perangkat tambahan, yang disebut dalam pengujian perangkat 2 , perangkat 3 , dan perangkat 4 .

Proses pengujian perangkat 2 user memasukkan username dan password yang sama. Hasilnya user ditolak oleh sistem untuk login. Dari hasil rekaman server, user memasukkan data username dan password yang sudah benar, tetapi server juga merekam bahwa mac address dari perangkat 2 tidak sesuai dengan yang tersimpan didalam database. Hal ini memperlihatkan flowchart desain model untuk sistem berjalan. Yang pertama sistem akan mengecek kesesuaian username, kemudian mengecek kesesuaian passwword, kemudian mengecek kesesuaian mac address, apabila sudah benar maka user dapat login. Jadi jika salah satu data yang masuk tidak sesuai dengan data yang 
tersimpan didalam database, sistem akan menolak user untuk login.

Untuk tetap bisa login menggunakan perangkat 2 , user harus login menggunakan perangkat 1 . Setelah itu, user dapat menambahkan nilai mac address dari perangkat lain ke database. User mencoba lagi untuk login menggunakan perangkat 2 , dan hasilnya user berhasil login.

Proses pengujian perangkat 3 dan 4 menggunakan proses yang sama seperti yang dilakukan pada pengujian perangkat 2 .

Dari pengujian menggunakan beberapa perangkat ini bisa dikatakan mac address dapat digunakan sebagai pengenal saat proses otentikasi dan bisa digunakan sebagai langkah untuk mengidentifikasi user.

Penulis juga menguji waktu saat proses login dari tiap-tiap perangkat. Hasilnya dapat dilihat pada Gambar 17.

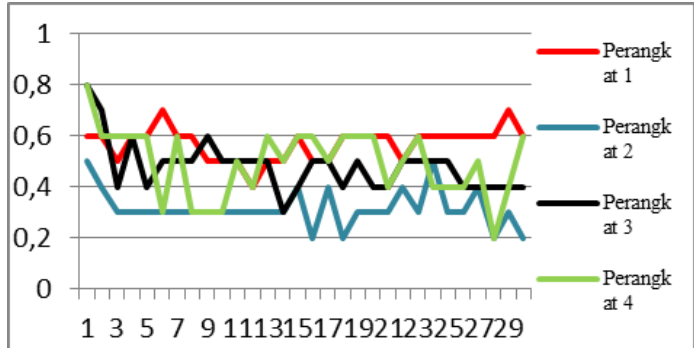

Gambar 17. Waktu Respon Perangkat Login

Respon waktu proses login semakin lama semakin cepat, tetapi saat memulai untuk login waktu yang digunakan lebih lama. Hal ini menunjukkan bahwa sistem saat pertama kali digunakan didalam server membutuhkan beberapa proses untuk memulai komunikasi. Setelah beberapa waktu komunikasi yang telah tersambung maka waktu untuk melakukan proses login semakin cepat, dan waktu yang cepat ini menunjukkan bahwa data password yang sudah dienkripsi dapat di proses dengan cepat, sehingga waktu respon login dari server tidak terpengaruh.

Otentikasi menggunakan mac address pada pengujian ini juga menunjukkan waktu respon dari server tidak berpengaruh banyak. Terlihat pada setiap grafik perangkat yang telah diuji dalam 30 percobaan login tidak ada yang mencapai 1 detik. Hanya saja ketika pertama kali masuk ke sistem diperlukan sedikit waktu untuk proses.

\section{KESIMPULAN DAN SARAN}

\section{Kesimpulan}

Dari hasil pengujian verifikasi dan validasi dapat disimpulkan bahwa model pengamanan akun saat otentikasi menggunakan mac address sangat mungkin untuk diterapkan. Model ini juga dapat digunakan secara efisien, karena dapat dilihat dari waktu respon 
yang dihasilkan masih bisa dikatakan sangat baik. Kemudian model ini dapat sebagai pengenal server untuk bisa memberikan akses login terhadap user dengan mengecek mac yang ada di perangkat yang digunakan oleh user.

\section{Saran}

Saran untuk penelitian berikutnya adalah mengimplementasikan model yang telah dibuat ini menjadi sebuah produk aplikasi yang dapat digunakan untuk mengamankan data didalam akun. Berikutnya adalah mengunakan metode enkripsi yang semakin kompleks dan mengenkripsi semua data yang digunakan oleh user saat proses login untuk melihat waktu respon server masih efisien.

\section{DAFTAR PUSTAKA}

Adikara, F. 2015. Pemanfaatan Mac Address Hostspot Dalam pengembangan sistem Absensi GPS Dalam Rangka Meningkatkan Keakuratan Posisi Pengguna. Jurnal SISFO: Inspirasi Profesional Sistem Informasi. 5: 4.

Al-Husainy, D., \& Fadhil, M. A. 2013. MAC address as a key for data encryption. arXiv preprint arXiv:1311.3821.

Khairina, D. M. 2011. Analisis Keamanan Sistem Login. Jurnal Informatika Mulawarman. 6:2 (64$67)$.
Maulana, A. 2014, Jutaan Password Pengguna Dropbox Dicuri Hacker, diakses tanggal 3 agustus 2016 <http://tekno.liputan6.com/read/211 8767/jutaan-password-penggunadropbox-dicuri-hacker $>$.

Nugroho, S.A. 2007. Analisa Algoritma Block Chiper dalam Penyandian DES dan Pengembangannya. Makalah. Sekolah Tinggi Elektro dan Informatika, Institut Teknologi Bandung. Bandung.

Rahardjo, Budi. 1999. Kemanan Sistem Informasi Berbasis Internet. Bandung: PT Insan Komunikasi.

Saikumar, I. 2017. DES-Data Encryption Standard. International Research Journal of Engineering and Technology. 4:3

Sulistyo, W dan Subanar. 2013. Desain Metodologi Penelitian Untuk Penelitian Dalam Bidang Ilmu Komputer. Seminar Nasional Sains dan Aplikasi Komputasi (SENSAKOM). Salatiga: UKSW.

Primartha, R. 2011. Penerapan Enkripsi dan Dekripsi File Menggunakan Algoritma Data Encryption Standard (DES). Palembang: Jurusan Sistem Informasi Fakultas Ilmu Komputer Universitas Sriwijaya. 